\title{
Od reportażu społeczno-obyczajowego do opowieści geohistorycznej. Ewolucja prozy Małgorzaty Szejnert
}

\author{
From Social Journalism to Geohistorical Writing. The Evolution of Małgorzata \\ Szejnert's Prose
}

\begin{abstract}
The essay discusses changes in Małgorzata Szejnert's writing, proposing a thesis that her journalist prose has evolved from social journalism to geohistorical writing. Her four so far, latest books: Czarny ogród (2007), Wyspa klucz (2009), Dom żótwia. Zanzibar (2011) and Usypać góry. Historie z Polesia (2015) are evidence that not until the $21^{\text {st }}$ century has she found her own, original and interesting writing style. A groundbreaking moment consisted in discovering the possibilities offered by exploring histories. Szejnert's writing became more mature, and finally it managed to combine the historical interest with the focus on the micro-world, the little corners of the globe, and their thorough description. Turning to geohistorical journalism didn't make Szejnert resign either from the distinct axiological element or from presenting topical issues; on the contrary, it opened much more possibilities to address, more broadly and in diverse contexts, the problems of our times.
\end{abstract}

Keywords: Małgorzata Szejnert, journalism, geohistorical writing

Streszczenie: Szkic omawia zmiany zachodzące w twórczości Małgorzaty Szejnert, stawiając tezę, iż jej proza reporterska przeszła ewolucję od reportażu społeczno-obyczajowego do opowieści geohistorycznej. Cztery, jak do tej pory, ostatnie książki autorki: Czarny ogród (2007), Wyspa klucz (2009), Dom żótwia. Zanzibar (2011) i Usypać góry. Historie z Polesia (2015) są dowodem na to, że dopiero w XXI wieku Szejnert znalazła swój własny, oryginalny i interesujący sposób pisania. Przełomowym momentem było odkrycie możliwości, jakie niesie zgłębianie historii. Od tego momentu twórczość Szejnert staje się bardziej dojrzała, by w rezultacie zaowocować udanym połączeniem zainteresowań historycznych ze skupieniem uwagi na mikroświecie, niewielkich zakątkach globu - ich dogłębnym opisaniu. Uprawianie reportażu geohistorycznego nie spowodowało rezygnacji ani z wyraźnego rysu aksjologicznego, ani z ukazywania aktualnych problemów, natomiast stworzyło znacznie więcej możliwości, by szerzej w różnorodnych kontekstach opowiedzieć o naszych współczesnych problemach.

Słowa kluczowe: Małgorzata Szejnert, reportaż, opowieść geohistoryczna 
Małgorzata Szejnert - debiutująca na początku lat siedemdziesiątych - ważne i niepowtarzalne miejsce w polskiej literaturze zajęła dość późno, choć przez wiele lat pisała reportaże i uczyła tej sztuki wielu młodszych autorów. Sposób pisania, który zaowocował szerokim czytelniczym rezonansem i wieloma nagrodami, Szejnert wypracowała sobie dopiero w XXI wieku. Do postawienia takiej tezy skłania lektura czterech jej ostatnich (jak do tej pory) książek. Czarny ogród (2007), Wyspa klucz (2009), Dom źótwia. Zanzibar (2011) i Usypać góry. Historie z Polesia $(2015)^{1}$ są dowodem na to, że Szejnert znalazła własny, oryginalny i interesujący „klucz” do opisu świata. Warto postawić pytanie o przebieg ewolucji twórczości Małgorzaty Szejnert. Spróbuję pokazać, które elementy twórczości reporterki od samych jej początków pozostały niezmienne, a których autorka dopracowała się z biegiem czasu, a także zmieniających się możliwości (nie bez znaczenia, trzeba to wyraźnie podkreślić, były polityczne warunki, w jakich przyszło jej żyć i pracować).

Omawiając twórczość Ryszarda Kapuścińskiego, badacze wyraźnie wskazują moment przełomowy. W zasadzie autor Cesarza w pewnej chwili sam zadeklarował: „tak więcej pisać nie będę...”2, więc była to świadoma zmiana stosunku do reporterskiego opisywania świata. U Małgorzaty Szejnert takiej cezury nie odnajdziemy, a jednak można postawić tezę, że jej proza ewoluowała od reportażu o tematyce obyczajowej ściśle ulokowanego w teraźniejszości do reportażu geohistorycznego. Pomiędzy tymi dwoma biegunami sytuują się trzy książki Szejnert: Szczecin: grudzień - sierpień - grudzień (1984) (napisana wspólnie z Tomaszem Zalewskim), wywiad-rzeka Stawa $i$ infamia. Rozmowa z Bohdanem Korzeniewskim (1988) i Śód żywych duchów (1990). Każda $\mathrm{z}$ nich - interesująca - stanowiła kolejny etap dochodzenia do wypracowanej metody twórczej.

\section{Reportaż społeczno-obyczajowy}

Maciej Siembieda, przyglądając się odmienności polskiego reportażu od „zagranicznych kuzynów", trafnie zauważał:

Zagraniczni kuzyni zawsze relacjonowali rzeczywistość taką, jaka była. Prosto i bez podtekstów: reporter jechał i przywoził czytelnikowi prawdę. Polski reporter tę samą prawdę przemycał. Przywoził tekst zaszyfrowany, nietykalny dla cenzury, ale zrozumiały dla wszystkich ${ }^{3}$.

${ }^{1}$ W roku 2013 na rynku księgarskim ukazała się jeszcze książka Małgorzaty Szejnert $M y$, wtaściciele Teksasu, ale zawiera ona przedruk reportaży z okresu PRL-u.

2 Zob. B. Nowacka, Z. Ziątek, Ryszard Kapuściński. Biografia pisarza, Kraków 2008, s. $190-222$.

${ }^{3}$ M. Siembieda, Reportaż po polsku, Poznań 2003, s. 9. 
„Przemycanie prawdy” nie było, co powszechnie wiadomo, jedynie domeną reportażu, niemniej także i w tym gatunku bardziej wybitni jego twórcy próbowali opowiedzieć o polskiej rzeczywistości, o jej nieprzystawalności do oficjalnie kreowanego obrazu. Natomiast - jak trafnie pisze Magdalena Piechota - „miarą ich [twórców - M.W.] mistrzostwa było znajdowanie środków i sposobów na wyrażanie między linijkami tego, o czym nie wolno było pisać wprost”". Piechota sytuuje PRL-owskie reportaże Szejnert w nurcie „małego realizmu" zgodnie z deklaracją samej autorki, która we wstępie do wydanego w 1977 roku zbioru reportaży pisała: „Zdaję sobie sprawę z niebezpieczeństw owego małego realizmu, a jednak w nim tkwię"5, ale świadoma wielu różnic, nie bez zastrzeżeń ${ }^{6}$. Charakteryzując reportaże Szejnert z tamtych lat, Piechota zwraca uwagę przede wszystkim na zainteresowanie autorki tak zwanym zwykłym człowiekiem, szczegółowość prezentacji bohaterów i drobiazgowość opisu?

To bez wątpienia istotne cechy twórczości Szejnert, nie tylko przecież autorki Borowików przy ternpajku. Badaczka sama wyrá́nie wskazuje, że zwykły człowiek to idealny bohater reportażu, a zbliżenie do szczegółu to częsta metoda obrazowania w utworach tego gatunku' ${ }^{8}$ Nic więc dziwnego, że każdy z tych elementów będziemy mogli odnaleźć w twórczości Szejnert od jej początków do dziś. Spróbujmy jednakże iść dalej i dopowiedzieć kilka kwestii. Mnie akurat PRL-owskie reportaże Szejnert - zwłaszcza w swoim podejściu do opisywania świata, do dokumentowania teraźniejszości - przywodzą na myśl nie prozę „małego realizmu”, a raczej felietonistyczną twórczość Stefana Kisielewskiego'. Podobnie jak u autora Sprzysiężenia tak i u Szejnert materią opisu była codzienność życia w tym „dziwnym ustroju”. Jak Kisiel pisała o „rzeczach małych” ${ }^{10}$, by pozwolić czytelnikowi zrozumieć „rzeczy duże”. Co ważniejsze, podobnie jak u Kisiela nie było ważne jedynie sprawne posługiwanie się językiem ezopowym, ale to, że opowiadaniu o świecie towarzyszy

${ }^{4}$ M. Piechota, Bohater ,matego realizmu”- zwykty cztowiek w reportażach Matgorzaty Szejnert („My, wtaściciele Teksasu”), „Zeszyty Naukowe KUL” 2015, nr 2, s. 73-90.

5 M. Szejnert, Od Autorki [w:] tejże, Ulica z latarnia, Warszawa 1977, s. 6.

${ }^{6}$ Magdalena Piechota pisze: „O ile jednak głosy krytyczne, z którymi spotkał się ten nurt literacki, wskazywały przede wszystkim na akceptację przeciętności, stereotypy zamiast obserwacji i banalność, o tyle można uznać, że ten sam krąg zainteresowań przyniósł w reportażu zgoła inne efekty, właśnie takie, które postulowali Julian Kornhauser i Adam Zagajewski w książce Świat nie przedstawiony z 1974 roku. Reportaże Małgorzaty Szejnert czy Hanny Krall z tego czasu odsłoniły bowiem podłoże »małej stabilizacji«, pozwoliły zobaczyć jej potoczny kształt”. M. Piechota, dz. cyt., s. 77.

7 Tamże.

8 Tamże.

${ }^{9}$ O felietonistyce Kisiela pisałam w książce: Sztuka felietonu Stefana Kisielewskiego, Katowice 2013.

${ }_{10}$ Por. S. Kisielewski, Rzeczy mate. Warszawa 1998, oraz wstęp do tegoż wydania: A. Michnik, Kpiarz heroiczny. Między Irzykowskim a Wiechem [w:] tamże. 
wyraźnie przypisany znak wartości. Elementy codzienności bohaterów składają się w rys aksjologiczny, co sprawia, że ów „teatr egzystencji” (fraza Aleksandra Nawareckiego) ${ }^{11}$ przemawia swoimi znaczeniami, a postaci stają się „nosicielami ogólności" ${ }^{2}$. Mariusz Urbanek pisze (co nota bene także silnie łączy postawę Kisiela i Szejnert) o wspólnej dla wszystkich książek autorki niezgodzie. To „Niezgoda na kłamstwo, na hipokryzję, obojętność, zapomnienie. Mówiąc najogólniej: niezgoda na milczenie. I przemilczanie"13. Szejnert podobnie jak felietonista upomina się więc o sprawy pozornie błahe, które zostały z oficjalnego dyskursu wykluczone, opowiada o świecie tak, by zarysować wyraźną alternatywę dla zideologizowanej narracji. Jeden z bohaterów następująco charakteryzuje przedwojenny handel:

U Meinla było tak: przychodziła klientka, mówiła „dzień dobry”, bo klient, owszem, musiał być witany, ale sam o „dzień dobry” nie zapominał. Opierała się o ladę i pytała: - Proszę pana, mam dziś przyjęcie dla tuzina gości, jaką pan radzi kawę, jaką herbatę, a jakie likiery? ${ }^{14}$

Wspomniałam o języku ezopowym, ale Szejnert nie stosuje nadmiernego kamuflażu. Nie tu leży wartość opisu ówczesnego świata. To obraz silnie zmodyfikowany przez artystyczne właściwości języka. Sposobem reporterki na opisanie rzeczywistości jest synekdocha. Autorka wykorzystuje tropy stylistyczne, jak również konkretne uogólnienie. Wybierając to, co dla danej rzeczywistości reprezentatywne, Szejnert odwołuje się do świadomości czytelnika, który potrafi rozpoznać tę rzeczywistość w okruchach, detalach, drobiazgach, takich jak wykonane przez „zmęczonego przymusowym lenistwem” architekta „tabelaryczne zestawienie konsekwencji pracy" z reportażu o takim właśnie tytule ${ }^{15}$, czy „stara sieczkarnia”, której historia rodzi tęsknotę do „rzetelności, do zdrowego sensu, do dobrej roboty" ${ }^{16}$.

Wydaje się, że po pierwsze, przekazywane wartości, po drugie, umiejętność wyboru „mikroskali” i po trzecie umiejętność posługiwania się językiem stworzyły to, co Magdalena Piechota nazywa „specjalnym rodzajem porozumienia, który i dla dzisiejszego czytelnika stanowi zaproszenie do wspólnego myślenia”" ${ }^{17}$.

11 A. Nawarecki, Czarna mikrologia [w:] Skala mikro w badaniach literackich, red. A. Nawarecki, M. Bogdanowska, Katowice 2005, s. 21.

12 Zob. E. Kasperski, Sprawa podmiotu. Szkic z antropologii literatury, „Przegląd Humanistyczny" 1993 , nr 5.

${ }_{13}$ M. Urbanek, Niezgoda na niepamięć, „Odra” 2016, nr 6, s. 3-7.

${ }^{14}$ M. Szejnert, Na samie i na tradycji [w:] tejże, My, wtaśsiciele Teksasu. Reportaże z PRL-u, Kraków 2013, s. 35.

15 Por. taż, Próba tabelarycznego zestawienia konsekwencji pracy... [w:] tejże, Ulica z latarnią, dz. cyt., s. 144 .

16 Taż, Tęsknota za stara sieczkarnią [w:] tejże, My, wtaściciele Teksasu, dz. cyt., s. 196.

${ }^{17}$ M. Piechota, dz. cyt., s. 80. 
Twórczość reporterską wyraźnie skoncentrowaną wokół tematyki społeczno-obyczajowej Małgorzaty Szejnert tamtego okresu możemy wpisać w omówioną przez Edwarda Balcerzana orientację socjologiczną ${ }^{18}$. Zainteresowanie bytowaniem małych społeczności, opowieść o „rzeczywistości peryferyjnej”, realistyczna obserwacja, werystyczna rzetelność i peryferie żywej mowy - to ważne, konstytutywne wyznaczniki tej orientacji ${ }^{19}$. Szejnert, pisząc o codziennym funkcjonowaniu pracowników sklepu-wizytówki, czyli warszawskiego Supersamu, o pracownikach zakładowej stołówki, codziennym życiu kilku wybranych pracowników Ursusa, egzystencji kobiety niewidzącej czy o mieszkańcach wieloetnicznej mazurskiej wsi, potrafi nie tylko celnie zrekonstruować socjologiczne fenomeny współczesności. Nierzadko ten Supersam czy zakładowa stołówka albo niezwykle ciekawa opowieść o budowie miasta Tychy stają się metaforami Polski, jej wielkimi metonimiami. Te umiejętności połączone z wyraźnie dostrzegalną wrażliwością społeczną reporterki można zauważyć we wszystkich książkach Szejnert.

\section{Spotkanie z historia}

Szczytowym momentem tej orientacji w twórczości Szejnert wydaje się książka - świadectwo czasów karnawału Solidarności - wydana wspólnie z Tomaszem Zalewskim Szczecin: grudzień - sierpień - grudzień. Reporterka miała okazję dobrze przyjrzeć się „tym wypadkom” - ludziom i atmosferze wówczas panującej, pomagając w sierpniu 1980 roku w redagowaniu biuletynu strajkowego w Stoczni im. Warskiego w Szczecinie. Książka powstała w czasie, kiedy misją literatury było wiarygodne opisanie, zapis doświadczenia czasu historycznego $^{20}$. Dla ewolucji twórczości reporterki istotne wydaje się, że poza rzeczywistością społeczną, która zawsze interesowała Szejnert, teraz ważne stanie się także spotkanie z żywą historią. Ryszard Kapuściński wielokrotnie podkreślał, że najbardziej fascynuje go w pracy reportera to, że może być świadkiem rodzącej się „na jego oczach” historii. Choć bez wątpienia teraźniejszość była tu

${ }^{18}$ E. Balcerzan, Przygody cztowieka książkowego (ogólne i szczególne), Warszawa 1990, s. 2425. Chociaż pozwalam sobie wykorzystać trafną klasyfikację Edwarda Balcerzana, to mam świadomość, że odnosi się ona do literatury fikcjonalnej, i chcę w tym miejscu zaznaczyć, że jestem przekonana o istnieniu granicy między twórczością reporterską a beletrystyczną. Argumenty za przywołaną tezą, jak również próbę dookreślenia, czym jest reportaż literacki, zamieściłam w teoretycznym rozdziale książki: Zobaczyć - opisać - zrozumieć. Polskie reportaże literackie o rosyjskim imperium (rozdział: Teoria reportażu literackiego), Katowice 2017.

19 E. Balcerzan, dz. cyt., s. 24-25.

20 O literaturze tamtych lat pisali między innymi: P. Czapliński, Ślady przetomu. O prozie polskiej 1976-1996, Kraków 1997; Z. Ziątek, Sierpień - grudzieńn - historia. Od dokumentów czasu do literatury miejsca [w:] Sporne sprawy polskiej literatury wspótczesnej, red. A. Brodzka, L. Burska, Warszawa 1998. 
impulsem, to Szczecin: grudzień - sierpień - grudzień to „wielki zapis czasu”, by zacytować Mariana Brandysa ${ }^{21}$. Lektura wspomnianego tomu skłania do konstatacji, że podobne doświadczenie stało się udziałem również i Małgorzaty Szejnert. Kilka cech charakterystycznych tekstu, w tym zamysł konstrukcyjny książki, pokazuje, że autorom nie chodziło jedynie o rejestrowanie „historii żywej”, a o wpisanie rewolucji solidarnościowej w szerszą perspektywę historiii ${ }^{22}$. Kiedy bowiem w części pierwszej autorzy rozpytują swoich bohaterów o ich przeszłość, „drogę do...”, dzielą ich życie zgodnie z najważniejszymi momentami historycznymi Polski dwudziestowiecznej. Mamy więc: wojnę, po wojnie, rok pięćdziesiąty, przed październikiem, rok pięćdziesiąty szósty, stabilizację, rok sześćdziesiąty ósmy i tytułowe: grudzień 1970, sierpień 1980 i grudzień 1981 roku. Świadomość zarówno życia bohaterów w ważnym czasie historycznym, jak i doniosłości historycznego momentu (ze świadomością tragicznego finału i bez nadziei na szczęśliwe zakończenie) podkreśla opisanie sierpniowych wydarzeń $\mathrm{w}$ formie diariusza, a także takie konstruowanie narracji, byśmy i dziś mogli uchwycić ów podniosły nastrój („Więc czekamy. Wielki spektakl rozpocznie się za półtorej godziny. Ten kolejny akt będziemy już oglądali na własne oczy"23). Wydaje się, że w twórczości Małgorzaty Szejnert był to punkt zwrotny, odtąd bowiem historia już na stałe zagości na kartach wszystkich pozostałych reporterskich książek.

Kolejna książka autorki wydana w 1988 roku w Londynie - Stawa $i$ infamia - to wywiad-rzeka ${ }^{24}$, rozmowa z profesorem Bohdanem Korzeniewskim, krytykiem i historykiem teatru, a jej tematem była kolaboracja polskich aktorów z okupantami w okresie drugiej wojny światowej. Nie jest to reportaż. Widać jednak nie tylko fascynację historią, ale także zarysowaną już metodę pracy Szejnert, polegającą na uzupełnianiu rozmów ze swoimi bohaterami rezultatami wysiłku i czasu spędzonego w archiwach. Wystarczy przeczytać kalendarium dołączone do tekstu głównego książki.

Historia i pamięć. Takim podtytułem można by opatrzyć kolejną (w zasadzie chyba równolegle pisaną ${ }^{25}$ ) książkę. Szejnert poszukuje miejsca, w którym grzebano ciała mordowanych przez UB stalinowskich więźniów, wśród

${ }^{21}$ Tej frazy użył Marian Brandys w dzienniku, kiedy pisał o zapiskach swojej żony Haliny Mikołajskiej dotyczących działalności opozycyjnej. M. Brandys, Dziennik 1976-1977, Warszawa 1996, s. 148.

${ }^{22}$ Taką właściwość niektórych pozycji dokumentarnych tamtych lat dostrzegł Zygmunt Ziątek w artykule Sierpieńn-grudzieńn- historia..., dz. cyt., s. 273-274.

23 Tamże, s. 239.

${ }^{24}$ Autorka wpisała się tym utworem w nurt literatury świadectwa (rozmowy Czesława Miłosza z Aleksandrem Watem, Kazimierza Moczarskiego z Jürgenem Stroopem czy Hanny Krall z Markiem Edelmanem), który Roman Zimand uznał za nowy gatunek dokumentu osobistego. Zob. R. Zimand, Rozmowa z ... - dokument czy literatura [w:] tegoż, Czas normalizacji. Szkice czwarte, Londyn 1989.

${ }^{25}$ W nocie wydawniczej o autorce, która została dołączona do wydania Stawy i infamii opublikowanego w Wydawnictwie Literackim w 1992 roku, odnotowano: „W latach 1988-1989 
nich generała Emila Fieldorfa „Nila” i rotmistrza Witolda Pileckiego. Grobów tych w zamyśle ówczesnych władz miało nie być. To poruszająca historia walki o pamięć, o ujawnienie prawdy o losach bliskich straconych w więzieniu przy ul. Rakowieckiej. Szejnert przyjmuje w tej książce rolę detektywa, dodajmy detektywa historycznego.

Poza wszystkim innym książka jest także interesującą prezentacją pracy reportera. Konwencja dziennika pozwala zobaczyć, jak autorka pracuje na materiale źródłowym ${ }^{26}$, jak zbiera poszlaki, szuka śladów, tych namacalnych i tych zachowanych jedynie w ludzkiej pamięci:

W którym roku zamieniono konia na silnik? Gdyby udało się to określić, można by zasłyszaną relację Weroniki Gładeckiej osadzić w krótszej przestrzeni czasu. To może przydać się później, jeśli po pytaniu - czy na Służewie grzebano więźniów? postawimy nowe - kiedy? ${ }^{27}$

Reporterka z roli detektywa historycznego już w żadnej ze swoich książek nie zrezygnuje. W mniejszym lub większym stopniu historia badana na postawie dostępnych, współczesnych źródeł stanie się fundamentem, osnową, na której Szejnert snuć będzie swoje opowieści.

Sród żywych duchów jest pierwszą książką reporterską, gdzie tak wyraźnie zaczyna się kształtować historyczny profil pisarstwa Szejnert; pisarstwa opartego na dogłębnych studiach, doskonałej znajomości epoki. Choć skupiony na konkretnych ludziach i ich problemach reportaż ten nasuwa rozliczne uniwersalne skojarzenia, umocowane etycznie. Dzięki temu stawał się okazją do rozmyślań nad skomplikowanym splotem ludzkich biografii w historii, a także rolą pamięci i pamiętania. „Co tu jest prawdą, a co grą wyobraźni lub podświadomości? Co w tych relacjach wynika z nowego, czynnego stosunku do sprawy (...), a co z zadawnionego strachu, bierności bezradności...(...)?”28 pyta Szejnert po spotkaniu z jednym ze swoich bohaterów. Pisząc ten reportaż, zapewne przyszło autorce doświadczyć, że gdy myślimy o pamięci, jak zauważył Wojciech Kalaga, nieuchronnie wkraczamy w obszar interpretacji:

Małgorzata Szejnert poszukiwała miejsc, w których grzebano więźniów politycznych straconych po wojnie w więzieniu mokotowskim w Warszawie" (s. 272).

${ }^{26}$ W początkowych partiach książki możemy przeczytać: „Wśród źródeł, w których szukam danych o straconych, są następujące: wspomnienia więzienne opublikowane głównie w podziemiu i przez polskie wydawnictwa na Zachodzie, relacje zapisane przeze mnie na taśmie magnetofonowej, trochę dokumentów ze źródeł prywatnych, książki i broszury o historii politycznej pierwszej powojennej dekady i o terrorze politycznym w Polsce, sprawozdania prasowe z procesów (...)". M. Szejnert, Śód żywych duchów, Kraków 2012, s. 76.

27 Tamże, s. 132.

28 Tamże, s. 139. 
Pamiętanie i interpretacja są więc w istocie dwoma nierozłącznymi aspektami tego samego działania; nie ma pamięci niezinterpretowanej, podobnie zresztą jak nie ma niezinterpretowanej historii $(. . .)^{29}$.

Pierwszy raz Szejnert zmierzyła się więc też z problemem uobecniania historii. Wędrówki/błądzenia po wszelakich magazynach pamięci, jakich doświadczyła już wówczas, uwrażliwiły ją na to, że zrekonstruowana przeszłość może istnieć jedynie w bardzo niedoskonałym kształcie, w sposób ułomny i niepełny ${ }^{30}$. Reporterka kończy książkę takim stwierdzeniem:

Pracowałam przez ponad półtora roku, ale informacje, które zgromadziłam, nie zaprowadzą nikogo na miejsce, w którym spoczywa mąż, ojciec lub brat. (...) Każda odpowiedź wywołuje nowe pytania ${ }^{31}$.

W omawianej pozycji widziałabym również pierwszy tekst (każdy następny w jakimś stopniu będzie potwierdzał to zainteresowanie autorki), w którym możemy dostrzec wspomnianą przez Urbanka niezgodę. Tym razem będzie ona dotyczyć zarówno deformacji pamięci, jak i fragmentów historii zepchniętych do zbiorowej niepamięci. Widać też, że Szejnert będzie interesowała nie tylko sama historia czy pamięć, ale także teraźniejszość. We wspomnianym reportażu umiejętnie wplata historię w nurt teraźniejszości. Tym samym czytelnik otrzymuje obraz ponurych powojennych lat oraz obraz końca lat osiemdziesiątych, czasu chylenia się ku upadkowi systemu niedemokratycznej władzy w Polsce.

\section{Reportaże geohistoryczne}

Nic nie sprzyjało zajmowaniu się historią w latach dziewięćdziesiątych. Pisarze „emigrowali” z wielkich historycznych tematów, należało „otworzyć okno i przewietrzyć pokój”, jak poetycko apelował do literatów Marcin Świetlicki ${ }^{32}$. $\mathrm{Ci}$, dla których nadal ważne były lata minione, odwoływali się do osobistego przeżycia historii, własnej biografii. Tej drogi Szejnert wybrać nie mogła, choćby z tego powodu, że twórcze wykorzystywanie własnej biografii nie ma wiele wspólnego z twórczością reporterską. I choć możemy jedynie podzielać żal Mariusza Urbanka, że nie stworzyła Szejnert obrazu pierwszych lat wolnej

29 W. Kalaga, Pamięć, interpretacja, tożsamość, „Teksty Drugie” 2012, nr 1-2, s. 39-58.

${ }^{30} \mathrm{O}$ formach pamięci i uobecniania przeszłości w literaturze pisał Marek Zaleski, Formy pamięci, Gdańsk 2004, s. 31.

${ }_{31}$ M. Szejnert, Śród żywych duchów, dz. cyt., s. 370.

${ }^{32}$ M. Świetlicki, Dla Jana Polkowskiego [w:] tegoż, Zimne kraje. Wiersze 1980-1990, Warszawa 1992. 
Polski w reportażach ${ }^{33}$, to być może autorce potrzebny był czas, by spojrzeć na historię nieco inaczej. By potraktować ją jako rezerwuar rozległej tradycji, wartej pamiętania, odpominania, ale zarazem pozwalającej na wnikliwy ogląd współczesności. Taką koncepcję opowiadania o historii możemy odnaleźć we wspomnianych przeze mnie w pierwszym akapicie czterech książach Szejnert napisanych w ostatnim dwudziestoleciu. Zarówno w Czarnym ogrodzie, Wyspie klucz, Domu żótwia. Zanzibarze, jak i w Usypać góry. Historiach $z$ Polesia możemy wskazać dwa plany opowieści: diachroniczny i synchroniczny. Ten pierwszy, jak nietrudno się domyślić, dotyczy właśnie historycznego aspektu tych książek, tu reporterka jest „badaczem biblioteki”, w której toczy interesującą rozmowę poprzez zderzanie ze sobą różnorodnych tekstów. Synchroniczny plan, w którym reporterka pełni funkcję antropologa prowadzącego obserwacje w wybranym miejscu, prowadzi ją do skonstruowania opowieści o współczesności wybranego geograficznego miejsca.

Nazwałam te reportaże geohistorycznymi, ponieważ specyfiką tej twórczości, autorskim idiomem Szejnert jest właśnie umiejętność przeplatania wspomnianych planów i dodatkowo łączenia zdystansowanej odreporterskiej narracji z historiami opowiedzianymi przez epizody z życia poszczególnych bohaterów zarówno tych współczesnych, którzy mogą opowiedzieć sami o sobie, jak i tych, których losy autorka rekonstruuje. Warto dodać, że powyższe stwierdzenia charakteryzują jedynie ramę owych opowieści. Każda z przywołanych książek stanowi realizację innego, osobnego zamysłu.

Reportaż Szejnert nie jest stricte historycznym w takim rozumieniu, jakim były na przykład książki Mariana Brandysa, który stworzył szczególny typ „reportażu z przeszłości”, odtwarzający charakterystyczny klimat obyczajowy epoki. Historia, choć zawsze jest ważnym elementem biografii bohaterów Szejnert, to inaczej niż w przypadku Ryszarda Kapuścińskiego czy Wojciecha Jagielskiego rozumiana jako zdarzenie z przeszłości, zdarzenie o wymiarze ponadjednostkowym (wojna, ludobójstwo czy zmiana ustrojowa), nie poprzedza i nie warunkuje powstania reportażu. Czy warunkuje go geografia? Bez wątpienia - jak twierdzi Joanna Tokarska-Bakir w recenzji Domu żótwia: „,formalnym kodem spinającym zebrane w książce opowieści jest obsesja lokalizacji” ${ }^{34}$. Nie wiem, czy jest to obsesja, jednak geografia pełni tu nie tylko funkcję „formalnego kodu spinającego". Geografia służy konstruowaniu mikroświatów. Małgorzata Szejnert „używa lupy” - bardzo dużego przybliżenia, by opowiedzieć czytelnikowi o jednym, niewielkim fragmencie ogromnej przestrzeni - Giszowcu i Nikiszowcu - małych wysepkach w morzu śląskości w Czarnym ogro$d z i e$, wyspach geograficznych: Ellis Island, Zanzibarze oraz o Polesiu - enklawie Poleszuków w przestrzeni tego fragmentu ziemi, którą zwykliśmy nazywać

${ }^{33}$ M. Urbanek, Niezgoda na niepamięć, „Odra” 2016, nr 6.

${ }^{34}$ J. Tokarska-Bakir, Biato-czerwone i czarne [recenzja książki M. Szejnert Dom żótwia. Zanzibar], „Gazeta Wyborcza” 2011, nr 265, s. 14. 
Kresami. Skoro topograficznie wyznaczona przestrzeń odgrywa tu ważną rolę, to warte zastanowienia wydaje się wykorzystanie instrumentarium geopoetycznego. W wypadku reportażu sprawa jednak nie jest prosta.

Kiedy Elżbieta Rybicka pyta o przedmiot geopoetyki, zastanawia się, czy poza podróżopisarstwem, reportażem i eseistyką jakieś inne gatunki literackie poddają się badaniu narzędziami geopoetyki ${ }^{35}$. Wydawałoby się więc, że niejako natura samego reportażu (w swojej przeważającej większości dotyczy przecież jakiegoś wybranego przez autora miejsca) predestynuje go do posługiwania się tą metodologią. Problem ten jest jednak bardziej złożony. Kiedy bowiem badaczka wymienia autorów, u których $\mathrm{z}$ łatwością można wskazać iż są, jak pisze Rybicka, „geograficzni”, wtedy z grupy postaci (Czesław Miłosz, Jarosław Iwaszkiewicz, Zygmunt Haupt, Jerzy Stempowski, Stanisław Vincenz, Władysław Terlecki, Józef Wittlin, Miron Białoszewski, Andrzej Kuśniewicz, Andrzej Stasiuk i Marcin Wilk) w zasadzie jedynie tych dwóch ostatnich z dużymi zastrzeżeniami można by zaliczyć do grona twórców reportaży literackich. Zwracam uwagę na tę specyficzną listę nie po to, by upomnieć się o twórczość reportażową. Wydaje się, że wybór tych nazwisk przez autorkę prac o geopoetyce jest znamienny i jednocześnie wyjaśnia, dlaczego narzędzia geopoetyczne nie dają się tak łatwo odnieść do reporterskiej twórczości. Można bowiem stwierdzić (a poszczególne przykłady literackie, które możemy w książce Rybickiej odnaleźć, to potwierdzaja), że wspomniane instrumentarium najbardziej sprawdza się w tych utworach literackich, gdzie nie tylko miejsce gra aktywną rolę, ale także - a może przede wszystkim - ważna jest relacja między miejscem a podmiotem. W przypadku zarówno Stasiuka, jak i Wilka możemy bez wątpienia mówić o ,ja” doświadczającym miejsca i piszącym o własnych widzeniach / olśnieniach / przeżyciach.

Przywołanie topografii wybranego fragmentu rzeczywistości nie służy w przypadku Szejnert kontemplacji czy smakowaniu przestrzeni, nie służy nawet temu, co badacze nazywają „,czytaniem przestrzeni”. To, co fascynuje Szejnert, to raczej problem czasu w tej przestrzeni skumulowanego. Trudno więc te reportaże zaliczyć do literatury, w której: „geografia nie jest rozumiana jako swoisty bierny pojemnik, w którym »wydarza sięu historia kultury, lecz aktywna siła, która wkracza w pole literackie i kształtuje je w głęboki sposób”36.

Geografia bez wątpienia wyznacza u Szejnert zakres opisu świata. W tym względzie propozycja autorki wydaje się minimalistyczna. W myśl zasady, że szkło powiększające może przybliżyć jedynie niewielki fragment obrazu, Szejnert zależy, by zobaczyć jak najwięcej, spojrzeć jak najgłębiej. Im mniejszy

${ }^{35}$ E. Rybicka, Geopoetyka. Przestrzeń i miejsce we wspótczesnych teoriach i praktykach literackich, Kraków 2014, s. 111.

${ }^{36}$ Taż, Geopoetyka (o mieście, przestrzeni i miejscu we wspótczesnych teoriach i praktykach kulturowych) [w:] Kulturowa teoria literatury. Gtówne pojęcia i problemy, red. M.P. Markowski, R. Nycz, Kraków 2006, s. 479. 
fragment przestrzeni, tym efekt wydaje się lepszy. W planie synchroniczno-geograficznym mamy więc mikro- a w planie synchronicznym makroogląd świata. Po raz kolejny wykorzystuje Szejnert konkretne uogólnienie, tym razem jednak w wymiarze diachronicznym. W historii małej wyspy Zanzibar czytelnik może zobaczyć obraz dwóch wieków kolonializmu; w Czarnym ogrodzie z opowieści o dwóch dzielnicach jednego miasta dowie się o historii kilku wieków istnienia Śląska i Ślązaków, w niewielkim skrawku Białorusi pozna wielowiekową i wielonarodową historię Polesia, a w mikroświecie amerykańskiej wyspy - czas tworzenia się Ameryki, jaką dziś znamy. Obie perspektywy - podkreślmy raz jeszcze - komplementarne względem siebie, podporządkowane są jednakże kwestii najważniejszej. Otóż punktem zarówno wyjścia, jak i dojścia nie jest dla Szejnert ani przeszłość, ani lokalność ${ }^{37}$. Centrum stanowi współczesność i interpretowanie zjawisk z punktu widzenia teraźniejszych problemów świata. Jeżeli nawet bierze autorka na warsztat tematy wydawałoby się stricte historyczne jak w Wyspie klucz, to nie tylko dlatego, by analizować zjawiska minione, ale by pomóc zrozumieć współczesność wybranego fragmentu rzeczywistości. Nieprzypadkowo historyk Marcin Kula podkreśla, że w przeciwieństwie do historyków reporterzy odważnie „doprowadzają swoje teksty aż do dzis'”38.

Gdy weźmiemy pod uwagę oba plany - geograficzny i historyczny, choć ten pierwszy wydaje się czymś nowym w ostatnich książkach Szejnert, to ten drugi zdaje się dominować. Wypracowując sobie sposób opowiadania o wybranym miejscu, tę historyczność autorka pogłębiła i zwielokrotniła, tak że plan diachroniczny można we wspomnianych pozycjach ująć w swoistą triadę. Jest (i była $-\mathrm{z}$ tej roli Szejnert nie wyszła, odkąd spisywała wydarzenia $\mathrm{z}$ lat „karnawału Solidarności”) autorka rekonstruktorką dziejów. Odkrywa i dramatyzuje wybrane wydarzenia z przeszłości, historię przez wielkie $\mathrm{H}$ opowiada pod postacią pojedynczych ludzkich losów. Jest również weryfikatorką. Nie tylko sprawdza obiegowe sądy i ustalenia, ale także krytycznie przewartościowuje obrazy rzeczywistości, o której pisze (jedne mity dekonstruuje, inne tworzy). Wreszcie - jest pisarką, która całość wybranych przez siebie zrekonstruowanych wydarzeń układa w kształt możliwie szerokiej panoramy oddającej klimat miejsca, a przede wszystkim budującą refleksję o współczesnych problemach naszej rzeczywistości. Spróbujmy się przyjrzeć wszystkim czterem książkom.

${ }^{37}$ Jeżeli przyjmiemy, jak interpretuje prace Michela Foucaulta Cezary Rosiński, że „Siłę lokalnego stanowi więc osobność, odrębność, inność, niemożność wyprowadzenia z niego sprawy ogólnej” (C. Rosiński, Śląska okolica, „Śląskie Studia Polonistyczne” 2013, nr 2, s. 323-324), to reportaże o Zanzibarze czy wyspie Ellis Island nie są reportażami „lokalnymi”.

${ }^{38}$ M. Kula, Reportaż historyczny jako rodzaj wspótczesnej historiografii [w:] Historia w kulturze wspótczesnej. Niekonwencjonalne podejścia do przesztości, red. P. Witek, M. Mazur, E. Solska, Lublin 2011, s. 302. Warto w tym miejscu dodać, że Marcin Kula podkreśla erudycyjność i źródłową solidność wspomnianych przez siebie reporterów, w tym Małgorzaty Szejnert. 
Jednym z ważkich problemów, które interesują autorkę Czarnego ogro$d u^{39}$, jest kwestia tożsamości w ciagle zmieniającej się „płynnej nowoczesności”. Szejnert, zajmując się Śląskiem (nie jest miejscowa, ogląda więc tę krainę z dystansu), próbuje pokazać, że tak naprawdę nie ma znaczenia, czy tożsamość śląska jest narodowa, czy etniczna. Istotne, że opiera się na nieprzemijających wartościach, a ich trwałość jest dla Szejnert bezdyskusyjna. „Nieważne - mówi jedna z bohaterek reportażu - do jakiego państwa należeć będzie Gieschewald, i tak nikt tych grządek, chałup i gospody nie ruszy ze Śląska. Nie darmo matki mówią: - Tam twa ojczyzna, synu, gdzie się z komina kopci”40.

Szejnert mitologizuje ten niewielki skrawek ziemi, tworząc dla niego osobne podanie $^{41}$. Już na samym początku czytelnik zostaje wprowadzony to w świat baśni, to Biblii:

Sto lat temu na Górnym Śląsku powstało osiedle, w którym miały rozkwitać cnoty rodzinne i pracownicze. Domy pod wysokimi dachami z gontu stały w jabłoniach, a jeśli któraś zaczynała marnieć, pracodawca wysyłał anioła, wielkiego mężczyznę w czarnych kamaszach, który przynosił zdrowy szczep i stawiał przy furtce. (...) Początek temu dał Adam. Nie pierwszy człowiek, lecz pierwszy Giesche ${ }^{42}$.

Mamy tu mityczne poszukiwanie początków, mamy implikację ogrodu rajskiego, w którym dominuje harmonia człowieka i natury ${ }^{43}$. Język chwilami zbliża się do poetyckiego ${ }^{44}$. „Znajduje tu swój wyraz [w mitologizowaniu - dop. M.W.] - jak pisze Edward Balcerzan - tęsknota do stałości świata"45. Tak ostentacyjne i - jak nazwał je Krzysztof Uniłowski - bezczelne mitologizowanie ${ }^{46} \mathrm{w}$ świecie przyspieszonych przeobrażeń w moim odczuciu jest przede wszystkim wyrazem tęsknoty za czymś trwałym, co można przeciwstawić wszechogarniającemu chaosowi jako pamiątkę świata uporządkowanego i sensownego. Interesujące wydaje się także, że Szejnert, konstruując ten mit, tworząc ponadto swoistą „encyklopedię wiedzy o Śląsku i Ślązakach” (myślę, że jest to najważniejsza książka o tym rejonie powstała po 1989 roku), inny mit

39 M. Szejnert, Czarny ogród, Kraków 2007.

40 Tamże, s. 89.

${ }^{41}$ O mityzacji historii w Czarnym ogrodzie wspominam także w książce: A. Dębska-Kossakowska, B. Gontarz, M. Wiszniowska, Literackie reprezentacje historii. Świadectwa-mediatyzacje-eksploracje, Katowice 2013.

${ }^{42}$ M. Szejnert, Czarny ogród, dz. cyt., s. 5.

${ }^{43}$ Więcej o mityzacji w Czarnym ogrodzie pisałam w: M. Wiszniowska, Między mitem, pamięcią i historia. Literacki obraz Ślaska w „Czarnym ogrodzie” Matgorzaty Szejnert, „Anthropos” 2014, nr 22-23, s. 25-33.

${ }_{44}$ Por. E. Balcerzan, dz. cyt., s. 25.

45 Tamże.

${ }^{46}$ K. Uniłowski, Czarny ogród, czyli maszyna do mieszkania, „Opcje” 2010, nr 2, s. 39-43. 
dekonstruuje: mit kształtowany przez wiele lat przez polską politykę historyczną, a opowiadający o kraju homogenicznym narodowo.

Szejnert lubi dekonstruować mity. Książka Usypać góry. Historie z Polesia ${ }^{47}$ traktuje o części „naszych mitycznych kresów” rozciągniętych nad Prypecią, Jasiołdą i Styrem, ukazuje skomplikowaną przeszłość miejsca wielonarodowościowego i wielowyznaniowego, która determinuje losy mieszkańców. Czytelnik towarzyszy autorce $\mathrm{w}$ próbach odnalezienia, zbadania i zrozumienia skomplikowanej tożsamości mieszkańców Polesia we wszystkich jej wymiarach i odmianach. Co ciekawe, autorka wykorzystuje te same elementy topografii symbolicznej, które spotykaliśmy w najbardziej rozpowszechnionej, literackiej wizji tych „obszarów tęsknot”"48: dom, rodzina, pejzaż, krajobraz. Ale u Szejnert ulegają one destrukcji. Najczęściej oglądamy ruiny, zgliszcza albo tropimy w krajobrazie to, co całkiem zniknęło już z powierzchni ziemi, jak choćby dwór Radziwiłłów czy słynna pińska flotylla. Dziś zniknęła już szansa, pisze Szejnert: „,...) pokazania tej krainy jeszcze spokojnej, patriarchalnej, zachowującej tradycyjną kulturę i światopogląd" ${ }^{49}$. Szejnert przygląda się miejscom zdegradowanym, odtwarza ich historie, także i te z polskimi bohaterami: Radziwiłłami, Wańkowiczami, Rodziewiczówną, rodziną Wysłouchów. Czy chce ocalić tamten czas od niepamięci? Tak, ale nie jako polonocentryczny mit czy legendę, ale jako opowieść o Poleszukach niosącą przede wszystkim walory poznawcze. Poza demitologizacją Kresów książka o Polesiu jest też, a może przede wszystkim, uniwersalną opowieścią o niezwykle trudnym procesie kształtowania tożsamości narodowej po historycznych zawirowaniach, w szczególności po latach komunistycznego wynarodawiania.

Współczesne mity bierze Szejnert na warsztat również w książce o maleńkiej wysepce w porcie miasta Nowy Jork, na której w latach 1892-1954 znajdowało się główne centrum przyjmowania imigrantów do USA. Był to ostatni przystanek na długiej drodze do ziemi obiecanej, jaką od wieków jest Ameryka, miejsce, w którym przesądzono o losie blisko 12 milionów osób. W Wyspie klucz $z^{50}$ Małgorzata Szejnert ukazuje dwa, wydawałoby się zupełnie przeciwstawne, choć na wyspie jakimś dziwnym trafem uzupełniające się, oblicza Ameryki. Z jednej strony, co wyraźnie autorka podkreśla, Ameryka to kraj kojarzony z etosem wolnościowym, z obietnicą lepszego życia. Kiedy opisuje podróż pułkownika Johna Baptiste’a Webera, pierwszego komisarza wyspy, do Rosji, autorka zwraca uwagę, że przypomina mu ona tę podjętą wcześniej przez markiza Astolphe’a de Custine’a. Rosja wprawiła obu w zdumienie, wywołała poczucie obcości. Weber pisał:

${ }^{47}$ M. Szejnert, Usypać góry. Historie z Polesia, Kraków 2015.

${ }^{48}$ Frazę zaczerpnęłam od Tadeusza Chrzanowskiego z jego książki: Kresy, czyli obszary tęsknot, Kraków 2013.

${ }^{49}$ M. Szejnert, Usypać góry, dz. cyt., s. 57.

50 Taż, Wyspa klucz, Kraków 2009. 
Rządy w Rosji i w Stanach Zjednoczonych przedstawiają sobą antypody, dwa krańce ludzkiej wolności. My tutaj mamy wolność wypowiedzi, tam nie można zebrać się publicznie bez zezwolenia władz; tutaj wolność prasy, tam cenzura rządowa. (...) Użycie hektografu jest zakazane, jeśli wcześniej nie uzyska się zezwolenia. Entuzjazm jest na rozkaz; flagi i chorągiewki rozmieszcza się z okazji państwowych według instrukcji policji ${ }^{51}$.

Z jednej strony Szejnert wyraźnie pokazuje czytelnikowi Amerykę jako młody kraj, ludzi pełnych pionierskiego entuzjazmu i dumy z jego demokracji, ale oprócz obrazu Stanów Zjednoczonych - krainy marzeń, aspiracji i nieograniczonych możliwości, historia Ellis Island to w dużej części zaprzeczenie mitu Ameryki liberalnej, tolerancyjnej i otwartej. Z etosem wolnościowym silnie kontrastuje proceder selekcjonowania imigrantów. Autorka stara się nie używać tego słowa, świadoma jego współczesnych konotacji, jednakże trudno odrzucić takie skojarzenia. Stany Zjednoczone nie życzyły sobie na swojej ziemi: „idiotów, chorych umysłowo, nędzarzy, poligamistów, osób, które moga się stać ciężarem publicznym, cierpią na odrażające lub niebezpieczne choroby zakaźne, były skazane za zbrodnie lub inne haniebne przestępstwa, dopuściły się wykroczeń przeciw moralności" ${ }^{2}$. Szejnert tej specyficznej listy nie komentuje. Zostawia czytelnika samego wobec jawnie eksterminującego stanowiska „rasy panów” w amerykańskim wydaniu.

Ellis Island jest więc kluczem do zrozumienia Ameryki współczesnej, jej tożsamości jako kraju, tożsamości amerykańskiego społeczeństwa i poszczególnych mieszkańców. Za symboliczne zamknięcie historii można uznać fragment: „Na dwadzieścia lat przed powstaniem muzeum otwarto World Trade Center na Manhattanie. W jedenaście lat po inauguracji muzeum w linii Manhattanu, widocznej z wyspy jak na dłoni, zabrakło dwóch wież"53.

We wszystkich przywołanych wyżej książkach Szejnert jest detektywem historycznym, jest nim także w książce o Zanzibarze ${ }^{54}$. W Domu żótwia opowiada historię społeczno-polityczną wyspy, począwszy od 1849 roku. Nie jest to jednak systemowy i systematyczny wykład. Jak w zasadzie we wszystkich ostatnich czterech książkach Szejnert zderza ze sobą historie wybranych bohaterów. Zanzibar wyłania się więc z opowieści o córce czerkieskiej branki księżniczce Salme, o władcach z rodów arabskich, handlarzu niewolników w Afryce Wschodniej Tippu-Tipie, przyrodniku i dyplomacie Johnie Kirku, czy śpiewaczce taarabu Bi Kidude. Ale książka o Zanzibarze nie jest jedynie opowieścią o niewielkim fragmencie afrykańskiego świata. Nie tylko o wyspie, którą możemy postrzegać jako drzwi do Afryki. (Stamtąd - wspomina

51 Tamże, s. 18.

52 Tamże, s. 23.

53 Tamże, s. 255.

54 M. Szejnert, Dom żótwia. Zanzibar, Kraków 2011. 
Szejnert - wyruszali wielcy podróżnicy: David Livingstone, Henry Morton Stanley, Richard Francis Burton i inni $\left.{ }^{55}\right)$. Dlaczego zainteresowała ją ta niewielka wyspa? W jednym z wywiadów powiedziała:

Dziś jest kluczem do zrozumienia epoki historycznej związanej z niewolnictwem i walką z nim, którą podjęła Wielka Brytania z powodów gospodarczych i politycznych, chociaż nie można wykluczać i humanitarnych. Także do zrozumienia rewolucji 1964 r. i wydarzeń porewolucyjnych: najpierw swoistej odmiany komunizmu, a potem powolnej demokratyzacji z korupcją i uwłaszczaniem władzy postkomunistycznej ${ }^{56}$.

Dom źótwia to przede wszystkim swoisty traktat o wolności i zniewoleniu. Dla Joanny Tokarskiej-Bakir już w samej historii Salme kryją się ważne pytania:

Czy Salme (...), córka czerkieskiej branki urodzona w zanzibarskim haremie i z tego tytułu nosząca tytuł księżniczki - jest wolna czy zniewolona? Czy wolny jest ktoś, kto wybiera honorową śmierć, bo jego oparta na wstydzie kultura tylko taki wybór mu zostawia? ${ }^{57}$

To Szejnert - kontynuuje badaczka - „zawdzięczamy przypomnienie, że wbrew ułatwionym interpretacjom niewolnictwo nie zostało do Afryki zawleczone przez kolonizatorów. Było tu od zawsze"58.

Temat wolności i zniewolenia pojawia się w biografiach poszczególnych bohaterów nie tylko gdy opowiada Szejnert o niewolnictwie, ale i o rewolucyjnej przemocy dwudziestowiecznych totalitaryzmów. W pojedynczych ludzkich losach, spersonalizowanych wątkach poznajemy historię aż do współczesnych tematów ekologicznych i globalistycznych. Niezwykle interesujące jest przy tym trafne diagnozowanie współczesności - już nie rasowego i ekonomicznego kolonializmu. Myślę, że próba odpowiedzi na pytanie o jego przyczyny prowadziła rękę Szejnert podczas komponowania tej książki, a pytanie o przyszłość Zanzibaru (a właściwie o skutki takiej ekonomicznej zależności) głośno wybrzmiewa po lekturze.

Przyglądając się ewolucji reporterskiej prozy Małgorzaty Szejnert, możemy zauważyć, że w ostatnich czterech książkach autorka wykorzystuje większość elementów warsztatu reportera, jakie możemy odnaleźć już w początkowej fazie jej twórczości. Skupienie na szczególe, zainteresowanie „zwykłym” człowiekiem dalej są ważne. W dalszym ciągu detal niesie ze sobą znaczenia

${ }_{55}$ Historyk bez patentu, z M. Szejnert rozmawia D. Lis, „Znak” 2011, nr 12, s. 90.

56 Tamże.

57 J. Tokarska-Bakir, Biato-czerwone i czarne, dz. cyt., s. 14.

58 Tamże. 
symboliczne (jak buttonhook - przyrząd do zapinania guzików stosowany także do wykrywania jaglicy z opowieści o Ellis Island czy kolkastra - pojemnik na węgiel malowany białą farbą albo choćby tytułowy żółwi dom).

Przełomowym momentem bez wątpienia było dla Szejnert odkrycie możliwości, jakie niesie zgłębianie historii. Od tego momentu jej twórczość jest coraz bardziej dojrzała, a jej realizację znajdujemy właśnie we wspomnianych książkach. Obok owego „zwykłego człowieka” pojawiają się bohaterowie, których znamy z literatury, historii, pierwszych stron gazet. Czy całkiem zrezygnowała Szejnert ze społeczno-obyczajowej tematyki w reportażach? Nic bardziej mylnego. Ona jedynie potrafi teraz ją umiejętnie wpleść tak, by stanowiła tylko preludium do ukazania problemów znacznie szerszych. I co ciekawe, Szejnert, dekonstruując mity bądź je tworząc, a także pochylając się nad ważnymi problemami każdego przywołanego przez siebie zakątka świata, nie zrezygnowała ani z wyraźnego rysu aksjologicznego, ani z ukazywania aktualnych problemów, natomiast uprawiany przez autorkę reportaż geohistoryczny pozwolił jej na znacznie więcej możliwości, by daleko głębiej o współczesnych problemach opowiedzieć.

\section{Bibliografia}

\section{Bibliografia podmiotowa}

Szejnert M., Borowiki przy ternpajku, Warszawa 1972.

Szejnert M., Czarny ogród, Kraków 2007.

Szejnert M., Dom żótwia. Zanzibar, Kraków 2011.

Szejnert M., I niespokojnie tu i tam, Olsztyn 1980.

Szejnert M., My, wtásiciciele Teksasu. Reportaże z PRL-u, Kraków 2013.

Szejnert M., Stawa i infamia. Rozmowa z Bohdanem Korzeniewskim, Londyn 1988.

Szejnert M., Sród żywych duchów, Kraków 2012 (wyd. 1, Londyn 1990).

Szejnert M., Ulica z latarnia, Warszawa 1977.

Szejnert M., Usypać góry. Historie z Polesia, Kraków 2015.

Szejnert M., Wyspa klucz, Kraków 2009.

Szejnert M., Zalewski T., Szczecin: grudzień - sierpień - grudzień, Szczecin 2008 (wyd. 1, Warszawa 1984; wyd. 2, Londyn 1986).

\section{Bibliografia przedmiotowa}

Balcerzan E., Przygody cztowieka ksiązkowego (ogólne i szczególne), Warszawa 1990.

Brandys M., Dziennik 1976-1977, Warszawa 1996.

Chrzanowski T., Kresy, czyli obszary tęsknot, Kraków 2013.

Czapliński P., Ślady przetomu. O prozie polskiej 1976-1996, Kraków 1997.

Dębska-Kossakowska A., Gontarz B., Wiszniowska M., Literackie reprezentacje historii. Świadectwa - mediatyzacje - eksploracje, Katowice 2013.

Historyk bez patentu, z M. Szejnert rozmawia D. Lis, „Znak” 2011, nr 12. 
Kalaga W., Pamięć, interpretacja, tożsamość, „Teksty Drugie” 2012, nr 1-2.

Kasperski E., Sprawa podmiotu. Szkic z antropologii literatury, „Przegląd Humanistyczny” 1993, nr 5.

Kisielewski S., Rzeczy mate, Warszawa 1998.

Kula M., Reportaż historyczny jako rodzaj wspótczesnej historiografii [w:] Historia $w$ kulturze wspótczesnej. Niekonwencjonalne podejścia do przesztości, red. P. Witek, M. Mazur, E. Solska, Lublin 2011.

Nawarecki A., Czarna mikrologia [w:] Skala mikro w badaniach literackich, red. A. Nawarecki, M. Bogdanowska, Katowice 2005.

Nowacka B., Ziątek Z., Ryszard Kapuściński. Biografia pisarza, Kraków 2008.

Piechota M., Bohater "matego realizmu” - zwykty cztowiek $w$ reportażach Matgorzaty Szejnert („My, wtaściciele Teksasu”), „Zeszyty Naukowe KUL” 2015, nr 2.

Rosiński C., Śląska okolica, „Śląskie Studia Polonistyczne” 2013, nr 2.

Rybicka E., Geopoetyka (o mieście, przestrzeni i miejscu we wspótczesnych teoriach i praktykach kulturowych) [w:] Kulturowa teoria literatury. Gtówne pojęcia i problemy, red. M.P. Markowski, R. Nycz, Kraków 2006.

Rybicka E., Geopoetyka. Przestrzeń i miejsce we wspótczesnych teoriach i praktykach literackich, Kraków 2014.

Siembieda M., Reportaż po polsku, Poznań 2003.

Świetlicki M., Dla Jana Polkowskiego [w:] tegoż, Zimne kraje. Wiersze 1980-1990, Warszawa 1992.

Tokarska-Bakir J., Biato-czerwone i czarne [recenzja książki M. Szejnert Dom żótwia. Zanzibar], „Gazeta Wyborcza” 2011, nr 265.

Uniłowski K., Czarny ogród, czyli maszyna do mieszkania, „Opcje” 2010, nr 2.

Urbanek M., Niezgoda na niepamięć, „Odra” 2016, nr 6.

Wiszniowska M., Między mitem, pamięcia i historia. Literacki obraz Ślaska w „Czarnym ogrodzie” Matgorzaty Szejnert, „Anthropos” 2014, nr 22-23.

Wiszniowska M., Sztuka felietonu Stefana Kisielewskiego, Katowice 2013.

Wiszniowska M., Zobaczyć - opisać-zrozumieć. Polskie reportaże literackie o rosyjskim imperium, Katowice 2017.

Zaleski M., Formy pamięci, Gdańsk 2004.

Ziątek Z., Sierpień - grudzień - historia. Od dokumentów czasu do literatury miejsca [w:] Sporne sprawy polskiej literatury wspótczesnej, red. A. Brodzka, L. Burska, Warszawa 1998.

Zimand R., Rozmowa z ... - dokument czy literatura [w:] tegoż, Czas normalizacji. Szkice czwarte, Londyn 1989. 